\title{
METHOD OF JUSTIFICATION FOR PARAMETERS OF TRACTOR-IMPLEMENT UNIT WITH REGARDS TO THEIR IMPACT ON CROP PRODUCTIVITY
}

\author{
Camill Khafizov, Azat Nurmiev, Ramil Khafizov, Nail Adigamov \\ Kazan State Agrarian University, Russia \\ fts-kgau@mail.ru, azat-nurmiev@mail.ru,ramilajz@mail.ru,n-adigamov@ rambler.ru
}

\begin{abstract}
Topicality of the research: the value of the research is caused by the need to optimize main parameters of an agricultural tractor during its operation, taking into account their influence on the crop and the actual absence of such optimization methods. Purpose of the study: the purpose of the work is to develop an energybased mathematical model of a tractor-implement unit (later - 'unit') to identify the optimal parameters of the tractor, the width of the implement and the speed of the unit, which increase the efficiency in terms of energy costs. Research methods: the main research method is mathematical modeling based on system analysis, field experiments and computational simulations. Results of the research: the paper describes the proposed structure of the system under study, a justified criterion for optimizing the tractor parameters, and some interdependencies of the proposed energy-based mathematical model parameters. As a result of use of the theory of similarity and the organization of six-factorial experiment, dependence of the maximum pressure of a wheel of the tractor on the soil is received. It is revealed that with increase in the wheel size, the width of its profile decreases in a vertical load on the wheel, the maximum pressure of the wheel on the soil decreases. It is found that in the structure of total energy costs the major part is accounted for by the energy of the crop lost due to the impact of machinery and the optimality of the unit parameters (from 40 to $80 \%$ depending on the type of operation, equipment used, operating conditions of units). Value: the proposed method of optimization of the main parameters of the tractor and unit will be useful in justifying the mass of the tractor and the power of its engine, both at the design stage of tractors and operations. The practical use of the research results benefits in a reduction of the total energy costs. The magnitude of reducing energy costs depends on the used tractors, agricultural machines and the conditions of their operation.
\end{abstract}

Keywords: tractor, unit, optimization, parameters, energy, mathematical model, harvest, losses.

\section{Introduction}

The sustainable development of agricultural business implies, along with other principles, also a continuous increase in labor productivity. In order to increase labor productivity in agriculture highly powerful tractors are supplied. With the increase in the traction power of the tractor, the issue of its effective operation becomes topical. The efficiency of the use of tractors and tractor-implement units on the basis of tractors depends on the features of the technological operation, the size of the fields, the optimality of the parameters and operation modes (both of the tractor and the tractor-implement unit as a whole) [1-17]. Previous researchers noted in their works that when optimizing the parameters of agricultural machinery, including tractors, it is necessary to use a systematic approach, to take into account the influence of parameters and operating modes of the technology on the final result of production - the yield of the cultivated crop [18-21].

It is also believed that for forecasting calculations, it is undesirable to use optimization criteria based on monetary units, because they are highly subject to subjective processes inherent in the financial environment [22-24]. The criterion of optimization should be complex, objective, synthesizing and consistent with the system under consideration, i.e. comprehensively describe it. It should allow to obtain optimal values of the parameters of the technology, which retain their stability for a sufficiently long period of time. Such a criterion can be the total energy costs per unit of work performed by the tractor and its implements [25].

This article proposes a scientific experimentally verified method for selecting a tractor with optimal basic parameters (tractor mass and engine power), and optimizing parameters (working widths) and operating modes (operating speed) of the tractor-implement units (TIU) on their basis, both at the design stage and at the stage of operation.

The peculiarity and novelty of the method is connected with the criterion of optimizing the parameters and operating modes of the tractor and the unit as a whole.

A substantiated criterion for optimizing the parameters of aggregates is most fully correlated with the crop formed through crop losses due to improperly chosen parameters of the technology. 
The research task is to reduce both direct and indirect energy costs and energy losses through grain.

\section{Materials and methods}

\subsection{Methodology and methods of the research}

The methodology accepted for the conducted research is based on the positions of system analysis [26]. The construction of system models relies on the intensive development of information technology. The main element of the system model is the formal system, which, unlike ordinary mathematical models - which are a set of equations, often based on the use of some mathematical apparatus, - includes various mathematical and logical modules, from which they create an algorithm for solving the problem. For tractor-implement units, the formal system is composed of the applied mathematical apparatus of the theory of engines, theory of tractors, operation of the tractor and implements fleet, empirical dependencies obtained using the theory of similarity, methods of mathematical statistics.

This also includes techniques, programs and algorithms that allow to calculate the effectiveness of the system - say, to determine the energy or monetary costs of the tractor-implement unit per unit of the work performed. Optimization of the parameters of the tractor and sowing unit is based on the use of numerical methods.

The scheme of studies using the system homeostatic model is shown in Fig. 1. Some features of system studies of machine-tractor aggregates follow from the following circumstances [26].

- The TIU system study assumes, starting with item 7 in Fig. 1, continuous refinement of the system model of sowing units, iterative studies and infinite in time approach to truth.

- Systemic studies suggest a constant refinement of the system model of units on the basis of experimental studies. The program, goals and tasks of experimental research are based on theoretical studies and computational experiments.

\subsection{Purpose of the study}

1. To justify the optimization criterion and develop an energy-based systematic mathematical model of the seeding machine to optimize the main parameters of the tractor, the width of the seeder and the moving speed of the unit, taking into account their influence on the crop.

2. To solve the problem, possible system variants and performance indicators of these systems and their elements that can be considered to achieve the stated goals and objectives of the study are analyzed - see Fig. 2 [27; 28]. The system of tractor-tool-operator-operator-field-soil-harvest (TTOFSH) was chosen as an object of the research. It was revealed that the more complex the system under consideration, the more generalizing, systemic, and complex should be the system's efficiency index in order to include all the partial indicators of the effectiveness of elements and subsystems of a complex system. This indicator is the total energy costs, which, in addition to direct and indirect energy costs, include, as an element, the energy of the crop lost due to the choice of not optimal tractor and TIU parameters.

The scheme for revealing the structure of the optimization criterion is shown in Fig. 3. To obtain the maximum energy output, when operating a tractor-implement unit, it is necessary to obtain the maximum yield with minimal energy costs. The maximum yield will be obtained, if we comply with the technological requirements for the performance of the technological operation - we carry out adjustments of the agricultural implement according to the instructions for their operation and observe the speed regime that ensures the required quality of the work performed. Therefore, the condition $[V]_{\min } \leq V_{p} \leq[V]_{\max }$ must be observed - the unit speed should not exceed the limits allowed by the technological requirements for the quality of the operation. This is the first limitation in the future mathematical model of the TIU. In addition, the value of the grown crop depends on the loss of the potential crop due to the violation of the technological terms of the technological operation and the negative impact of the tractor wheels on the soil. The crop losses can be reduced by optimizing the parameters and operating modes of the MTA, as well as a combination of direct and indirect energy costs. 
The second limitation in the future mathematical model of the TIU is based on the fact that the required power $N_{e}$ for the operation of the TIU should not exceed the rated power of the engine $N_{e n}$, and the slip of the tractor wheels $\delta$ should be within the permissible range $[\delta]$, i.e.

$$
N_{e} \leq N_{e n}, \delta \leq[\delta] .
$$

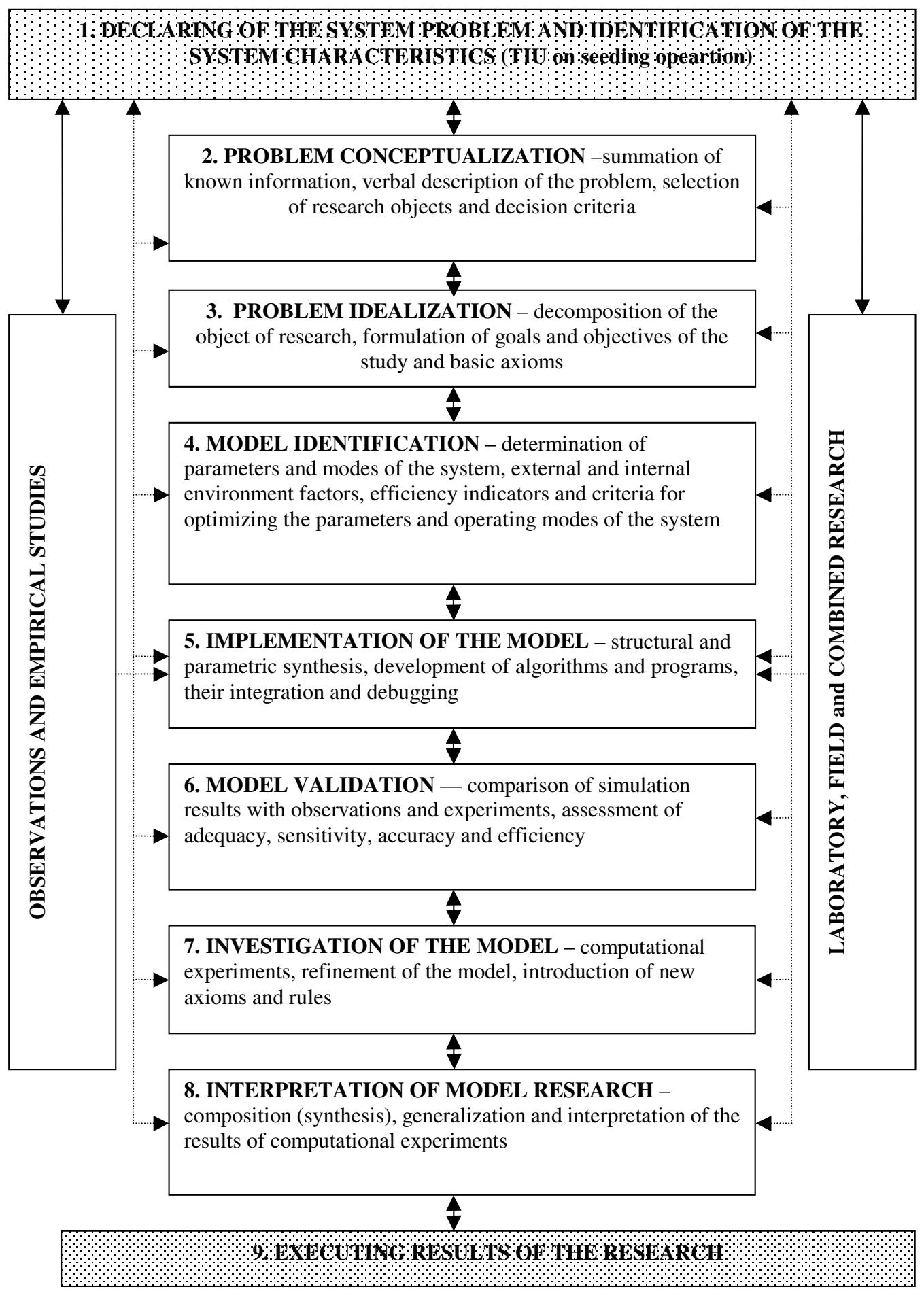

Fig. 1. Scheme of conducting system studies of machine and tractor units on sowing

The energy criterion for optimizing the parameters and operating modes of the tractor and TIY on seeding as a whole will look as follows [25]:

$$
E=E_{\mathrm{m} . \mathrm{tr}}+E_{\mathrm{m} . \mathrm{imp}}+E_{\mathrm{rts}}+E_{\mathrm{u} . \mathrm{c} .}+E_{\mathrm{drv}}+E_{\mathrm{fo}}+E_{\mathrm{agr}}+E_{\mathrm{exp}} \rightarrow \min ,
$$

where $E$ - specific total energy expenditure, $\mathrm{MJ} \cdot \mathrm{ha}^{-1}$; 
$E_{m . t r}, E_{m . i m p}$ - energy spent, respectively, for the manufacture of a tractor and agricultural machine, per 1 hectare, $\mathrm{MJ} \cdot \mathrm{ha}^{-1}$;

$E_{r t s}$ - energy spent on all types of repair and technical service of a tractor and agricultural implement, MJ $\cdot$ ha $^{-1}$;

$E_{\text {u.c. }}-$ energy spent on assembling and disassembling the seeding unit, $\mathrm{MJ} \cdot \mathrm{ha}^{-1}$;

$E_{d r v}$ - energy spent by the machine operator on the control of the unit (turning, stopping and starting and shifting gears), MJ.ha ${ }^{-1}$;

$E_{f o}$ - energy spent for fuel, MJ $\cdot \mathrm{ha}^{-1}$;

$E_{a g r}$ - energy of the crop lost due to a violation of the technological terms of the technological operation, $\mathrm{MJ} \cdot \mathrm{ha}^{-1}$;

$E_{\text {exp }}$ - energy of the crop lost due to soil compaction by the tractor wheels, MJ.ha ${ }^{-1}$.

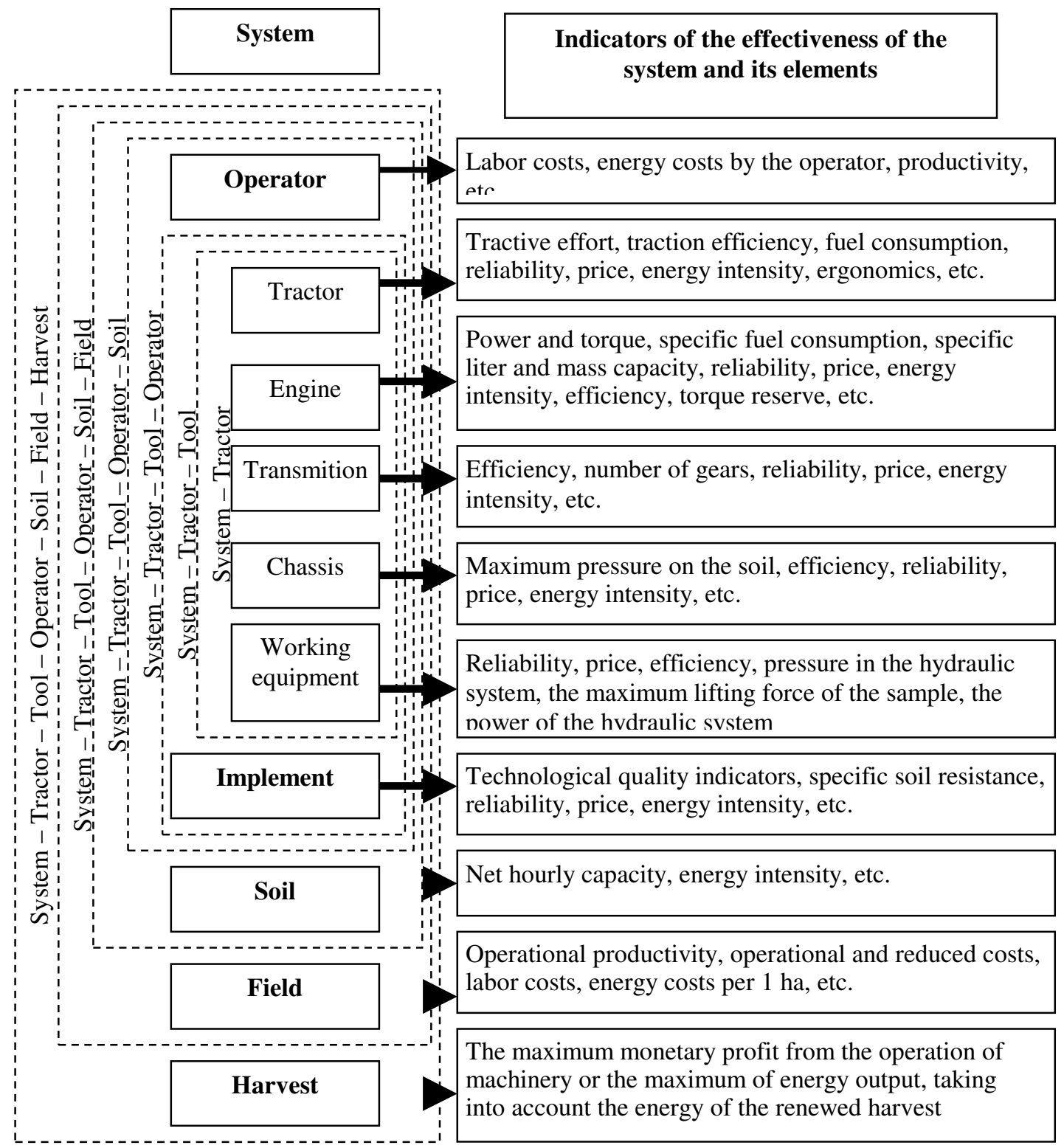

Fig. 2. Possible variants of studied systems and indicators of effectiveness of systems and their elements

The problem of constructing an energy-based system mathematical model is reduced to determining the dependence of each component of the total energy costs (1) (modules) on the main parameters of the tractor and the unit. To date, there are no calculation methods and corresponding mathematical models to optimize the main parameters of the tractor (the mass of the tractor and the power of its engine), taking into account their influence on the crop formed. The compilation of such 
systematic energy-based mathematical model of the TIU for optimizing the main parameters of the tractor will have a novelty and practical significance.

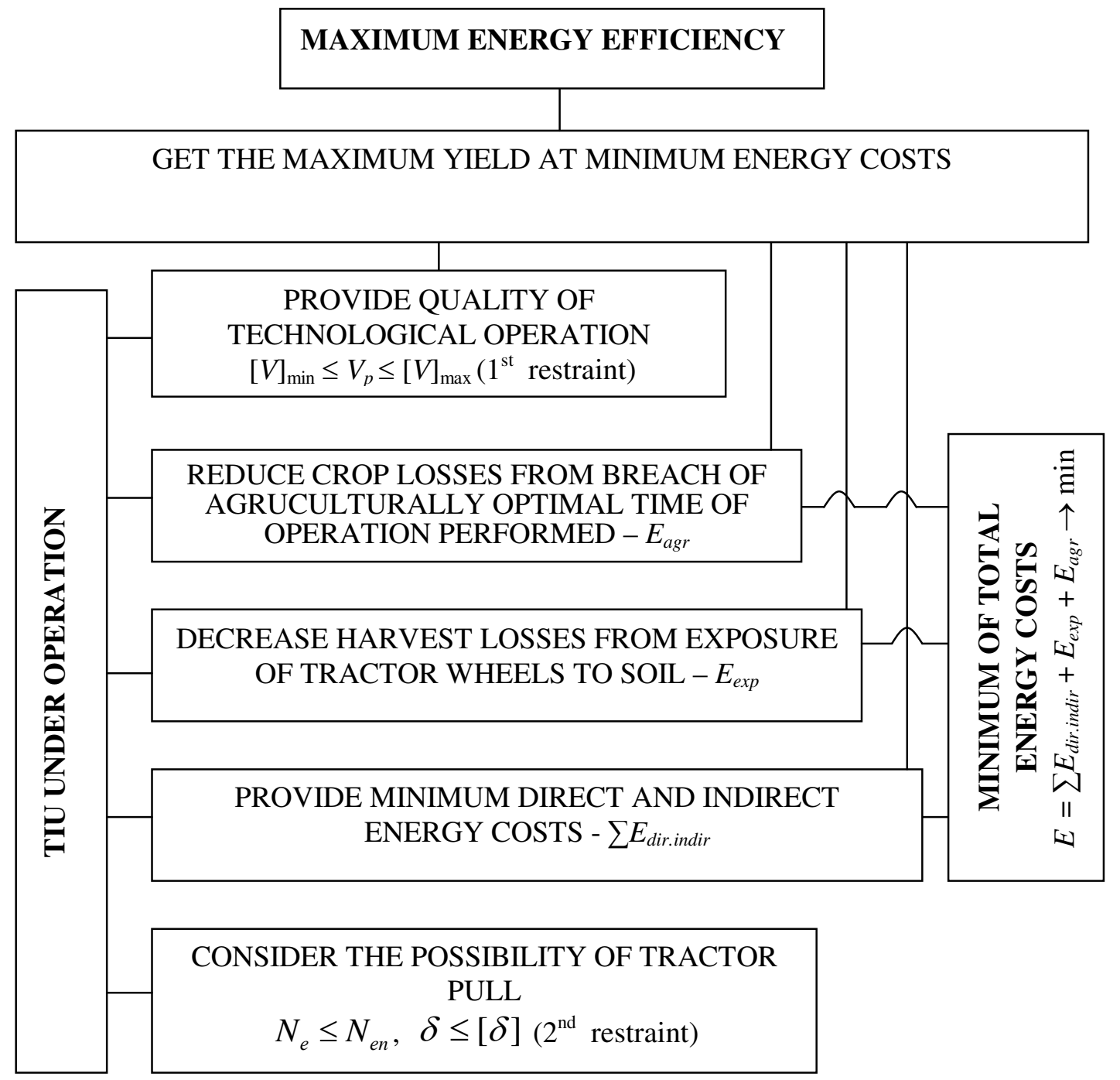

Fig. 3. Scheme to determine criterion of optimization for tractor and TIU main parameters

\section{Results and discussion}

The procedure for calculating the components of the total energy costs of $E_{\mathrm{m} . \mathrm{tr}}, E_{\mathrm{m} . \mathrm{imp}}, E_{\mathrm{rts}}$, $E_{\text {u.c. }}, E_{\mathrm{drv}}, E_{\mathrm{fo}}$ is given in [24].

Errors in choosing a tractor, parameters and operating modes of sowing units lead to crop losses. The loss of crops from violation of the agro-operation is determined by the following model (2), (3), (4) $[24]$ :

$$
E_{a g r}=\frac{\sum_{i=1}^{N_{i}-1}\left(\tilde{N}_{\mathrm{L}} i W \grave{O}_{\mathrm{sh}} n_{\mathrm{sh}}\right)+\left(N_{i}+1\right) \Delta i C_{\mathrm{L}} W_{s h} \grave{O}_{\mathrm{sh}} n_{\mathrm{sh}}}{S_{0}},
$$

where $C_{\mathrm{L}}$ - yield loss coefficient, MJ.ha per day ${ }^{-1}$

$$
C_{\mathrm{L}}=Y \Delta y Q / 100,
$$

where $\quad Y$ - planned yield, $\mathrm{kg} \cdot \mathrm{ha}^{-1}$;

$\Delta y-$ loss of crop in \% for 1 day of violation of the optimal operation timings;

$Q$ energy intensity of $1 \mathrm{~kg}$ of product (grain), $\mathrm{MJ} \cdot \mathrm{kg}^{-1}$;

$N_{i}$ number of whole days in $\mathrm{N}_{1}(4)$; 
$\Delta i$ - residual incomplete day in $N_{1}$;

$S_{0}$ - volume of work per season, per one seeding unit, for this operation, ha;

$$
N_{1}=\frac{S_{0}}{W_{\text {sh }} T_{\text {sh }} n_{\text {sh }}},
$$

where $N_{1}$ - number of days required to perform the operation on the area $S_{0}$;

$n_{\mathrm{sh}}-$ coefficient of shifts;

$T_{\mathrm{sh}}-$ duration of shift, hours.

To calculate the energy of the crop lost due to compaction of the soil, we use the equation [23]:

$$
E_{\text {exp }}=A Y Q\left(\frac{B_{1}}{2 B_{p}} \sum_{j=1}^{n} w b_{k} q_{\max }+[U] \cdot\left(1-\frac{n B_{1}}{2 B_{p}}\right)-[U]\right) / 100,
$$

where $A$-coefficient determining the percentage of lost crop per unit of sealing action of tractor wheels, $\% \cdot \mathrm{m} \cdot \mathrm{kN}^{-1}$;

$Y$ - planned yield, $\mathrm{kg} \cdot \mathrm{ha}^{-1}$;

$Q$ - energy intensity of $1 \mathrm{~kg}$ of product, $\mathrm{MJ} \cdot \mathrm{kg}^{-1}$;

$B_{1}$ - width of the impact zone of the compacting effect of the tractor on the yield of crops on the field (in the approximate calculations $B_{1}=10.8 \mathrm{~m}$ );

$B_{P}$ - working width of TIU, including the given tractor, m;

$n$ - total number of traces of wheels left by the tractor on the field in one pass;

$w$-coefficient, depending on the size and shape of the support surface of the propellers (for wheel propulsion $w=1.25$ );

$b_{k}$ - width of the wheel profile, $\mathrm{m}$;

$q_{\max }-$ maximum pressure of an individual tractor wheel on the soil, $\mathrm{kPa}$;

$[U]$ - permissible level of sealing effect of the tractor wheel on the soil, below which the decrease in the crop yield does not occur $=75 \mathrm{kN} \cdot \mathrm{m}^{-1}$.

In given model (5), the parameter $q_{\max }$ is indeterminate, since it depends on the parameters of the tractor, its wheels and soil properties. To determine the formula for its calculation, experimental studies based on the theory of similarity and planning of multifactorial experiments were carried out. As a result, the equation $[29,30]$, adequately reflecting the results of other researchers $[31,32]$ :

$$
q_{\max }=3.46 \rho_{w}-7.4493 B \rho_{w} / D+0.075552 H-0.23353\left(\rho_{n} \rho_{w} D^{3}\right) / M ;
$$

where $q_{\max }-$ maximum wheel pressure on the soil, $\mathrm{N} \cdot \mathrm{m}^{-2}$;

$D$ - wheel diameter, $\mathrm{m}$;

$M$ - mass of the tractor per one wheel, $\mathrm{kg}$;

$B$ - wheel profile width, m;

$H$ - hardness of the soil, $\mathrm{Pa}$;

$\rho_{n}-$ soil density, $\mathrm{kg} \cdot \mathrm{m}^{-3}$;

$\rho_{w}$-air pressure in the tires, $\mathrm{N} \cdot \mathrm{m}^{-2}$.

The simultaneous effect on the magnitude of the maximum wheel pressure on the soil of three factors (6) is shown in Fig. 4.

Data for calculation:

$$
\begin{aligned}
\rho_{w} & =1.6 \times 10^{5} \mathrm{~N} \cdot \mathrm{m}^{-2} ; H=15 \times 10^{5} \mathrm{~N} \cdot \mathrm{m}^{-2} ; \rho_{n}=1500 \mathrm{~kg} \cdot \mathrm{m}^{-3} ; \\
{[\mathrm{B}, \mathrm{D}, \mathrm{M}] } & =\operatorname{meshgrid}(0.1: 0.0375: 0.7,1.3: 0.06875: 2.4,1000: 200: 4200) .
\end{aligned}
$$

The greater the pressure of the wheel on the soil, the more intense the bright red color is the surface of the cube. With a decrease in the diameter of the wheel, the width of its profile and the increased load on the wheel, the maximum wheel pressure on the soil increases.

With the use of the developed energy-based mathematical model of units, computational experiments were carried out to identify the optimal basic parameters of the tractor working in the composition with seeding and tillage units (the results will be given in the following articles). It is necessary to pay attention to the structure of the components of the total energy costs. In the structure of the total energy costs, shown in Fig. 5, the main share falls on the energy of the crop lost due to the 
impact of the technology on it and the optimality of the unit's parameters (from 40 to $80 \%$ depending on the operation, the tractor brand and the agricultural machine). Therefore, in order to obtain objective data, consideration of this component of the optimization criterion is a very important task.

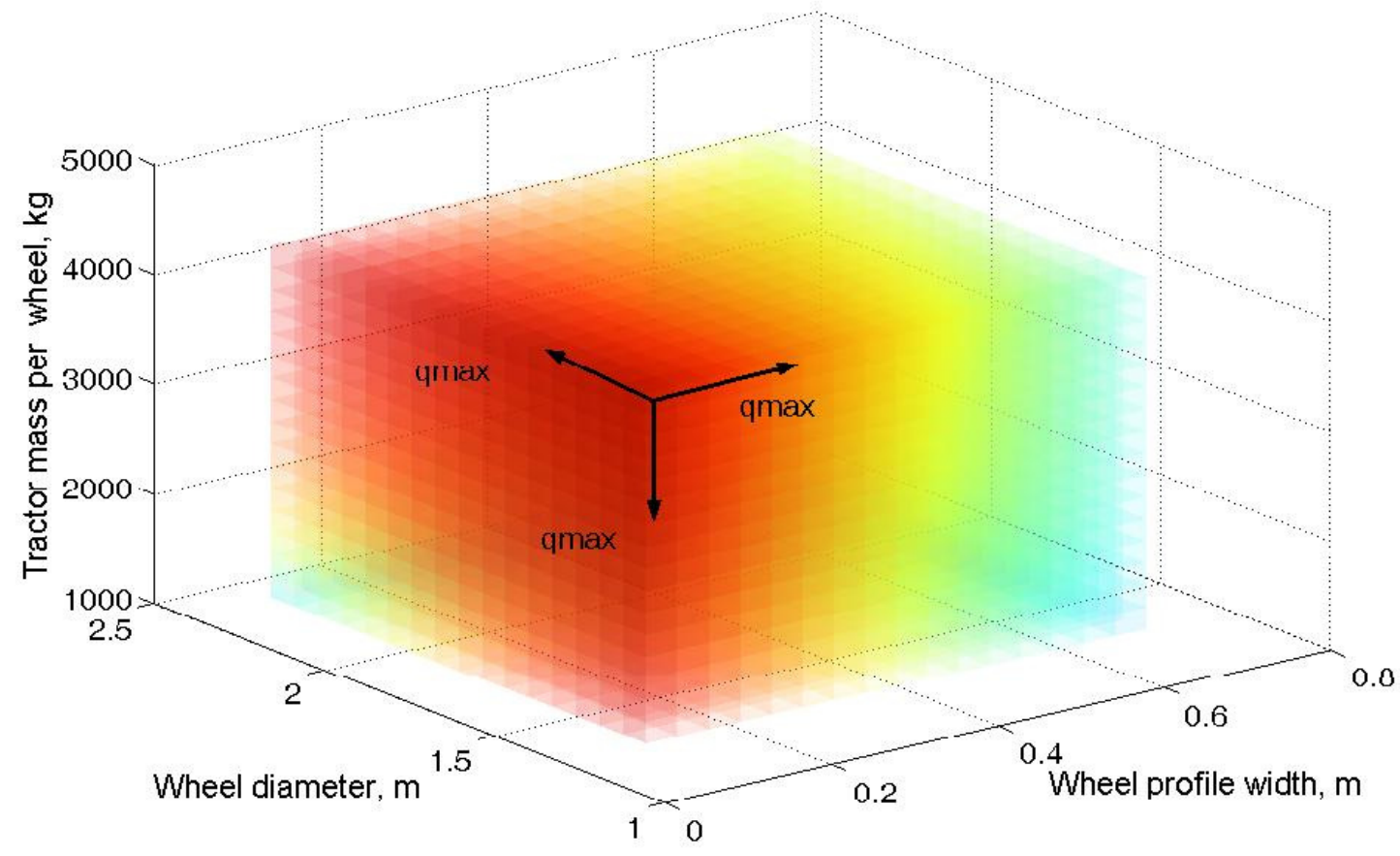

Fig. 4. Change of maximum wheel pressure on soil with change in width of profile, diameter of wheel and weight of tractor per wheel

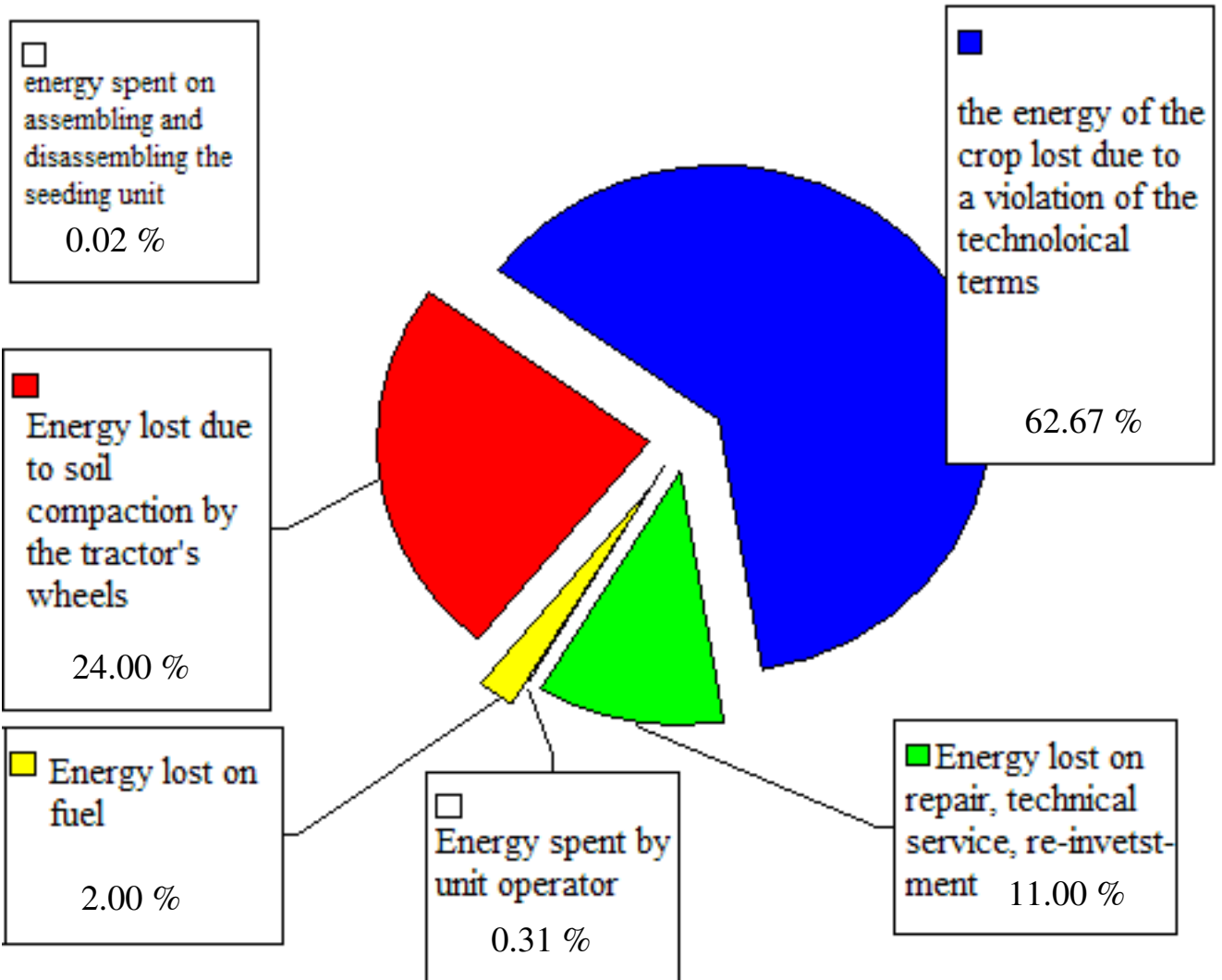

Fig. 5. Example of diagram of ratio of structure components of total energy consumption in crop with crawler tractor 


\section{Conclusions}

1. The purpose and objectives of the research are formulated in the work. The system of tractor-tooloperator-operator-field-soil-harvest (TTOFSH) was chosen as the object of the research. It was revealed that the more complex the system under consideration, the more generalizing, systemic, and complex should the system's efficiency index be in order to include all the partial indicators of the effectiveness of elements and subsystems of the complex system. This indicator is the total energy costs, which, in addition to direct and indirect energy costs, include, as an element, the energy of the crop lost due to the choice of not optimal tractor and MTA parameters.

2. As a result of using the similarity theory and organizing a six-factor experiment, the dependence of the maximum pressure of the tractor wheel on the soil was obtained. It is revealed that with increasing the wheel diameter, width of its profile, reduction of the vertical load on the wheel the maximum pressure of the wheel on the soil is reduced. Thus, all equations for calculating each component of the optimization criterion from the parameters of the tractor, aggregate and environmental factors are established and a new methodology for justifying the main parameters of the tractor (tractor weight and engine power), parameters and operating modes of the unit is proposed.

3. It is revealed that in the structure of total energy costs the main share is taken by the energy of the crop lost due to the non-optimality of the parameters and operating conditions of the tractor and the unit - from 40 to $80 \%$. When optimizing the parameters and operating modes of machinetractor aggregates, consideration of this component of the energy optimization criterion is a very urgent task.

4. The proposed methodology for optimizing the main parameters and operating modes of the tractor (weight of the tractor and the power of its engine) and the unit (the width of capture and speed) can be used to justify the parameters of the tractor and the unit both at the design stage and at the stage of operation of available tractors and agricultural implements at the enterprises of commodity producers in order to reduce the total energy costs and, in particular, to reduce the amount of lost crop.

\section{References}

[1] Adsit A.H., Clark R.L. Tractive and energy performance of a small four-wheel drive tractor. ASAE Paper No. 81-1042, ASAE, St. Joseph, MI 49085, 1981.

[2] Upadhyaya S.K., Ma T.X., Chancellor W.J., Zhao Y.M. Dynamics of soil-tool interaction Soil Tillage Res., 9 (1987), pp. 187-206.

[3] Scarlett A. J. Integrated control of agricultural tractors and implements: review of potential opportunities relating to cultivation and crop establishment. Computers and Electronics in Agriculture, 30: 2001, pp. 167-191.

[4] Stombaugh T. S., Benson E. R., Hummel J. W. Guidance control of agricultural vehicles at high field speeds. Transactions of ASAE, 42(2), 1999, pp. 537-544.

[5] Givan W., Hammond C. Selection of Farm Tractors. Cooperative Extension Service. University of Georgia College of Agriculture. Athens, GA. Miscellaneous Publication Number 68, 1978.

[6] Ansorge D., Godwin R.J. The effect of tires and a rubber track at high axle loads on soil compaction - Part 1: Single axle-studies. Biosyst. Eng. 98, 2007, pp. 115-126.

[7] Ansorge D., Godwin R.J. The effect of tires and a rubber track at high axle loads on soil compaction - Part 2: Multi-axle machine studies. Biosyst. Eng. 99, 2008, pp. 338-347.

[8] Ansorge D., Godwin R.J. The effect of tires and a rubber track at high axle loads on soil compaction - Part 3: Comparison of virgin compression line approaches. Biosyst. Eng. 104, 2009, pp. 278-287.

[9] Arvidsson J., Westlin H., Keller T., Gilbertsson M. Rubber track systems for conventional tractors - Effects on soil compaction and traction. Soil Till. Res. 117:, 2011, pp. 103-109.

[10] Batey T. Soil compaction and soil management - a review. Soil Use Manage. 25, 2009, pp. 335-345.

[11] Chamen W.C., Moxey A.P., Towers W., Balana B., Hallett P.D. Mitigating arable soil compaction: review and analysis of available cost and benefit data. Soil Till. Res. 146, Part A, 2015, pp. 10-25. 
[12] Håkansson I., Reeder R.C. Subsoil compaction by vehicles with high axle load-extent, persistence and crop response. Soil Till. Res. 29, 1994, pp. 277-304.

[13] Schjønning P., Lamandé M., Tøgersen F.A., Arvidsson J., Keller T. Modelling effects of tire inflation pressure on the stress distribution near the soil-tire interface. Biosyst. Eng. 99, 2008, pp. 119-133.

[14] ASAE, St Joseph, Mi, USA. Reid J.T. A comparison of the energy input of some tillage tools. ASAE Paper 78-1039, 1978.

[15] John Deere Road, Moline, Illinois, 61265, USA. He, C.S.; Lui X. L., Zhang D. J., Yang X.W. (1989). Methodological research on agricultural machinery selection. Proceedings of the internation al symposium on agricultural engineering (89 - ISAE) Beijing China 12 - 15 September, 1989, pp. 118-121.

[16]Галиев И.Г., Хусаинов Р.К. Оценка условий функционирования в сельскохозяйственном производстве (Assessment of operating conditions in farm-production), The machinery and equipment for the village: Техника и оборудование для села. 2015. - № 10. - С. 13 - 15. (in Russian)

[17]Галиев И.Г., Хусаинов Р.К. Определение перечня факторов характеризующих условия эксплуатации тракторов (Definition of the list of factors of the tractors characterizing operating conditions), ), Bulletin of Kazan State Agrarian University: Вестник Казанского государственного аграрного университета. - Казань, 2015. - № 3. - С. 77 - 88. (in Russian)

[18]Ксеневич И.П., Гуськов В.В., Скойбеда А.Г. О системном методе прогнозирования параметров сельскохозяйственных агрегатов (On the system method for predicting the parameters of agricultural aggregates). Tractor and Implements: Тракторы и сельхозмашины, 1976, No.8, pp. 3-5. (in Russian)

[19]Ксеневич И.П., Скотников В.А., Ляско М.И. Ходовая система - почва - урожай (Chassis soil - harvest). Moscow, Agropromizdat: Агропромиздат, 1985.-304 p. (in Russian)

[20]Тракторы. Проектирование, конструирование и расчет. Учебник для студентов машиностроительных специальностей вузов (Tractors. Design, construction and calculation. Textbook for students of machine-building specialties of universities), И. П. Ксеневич, В. В. Гуськов, Н. Ф. Бочаров и др.; Под общ. ред. И. П. Ксеневича, Moscow: Mashinostroenie: Машиностроение, 1991, 544 p. (in Russian)

[21]Lavoie, G., Gunjal, K. and Rahavan, S.V. (1991). Soil compaction, machinery selection and optimum crop planning. Transactions of American Society of Agricultural Engineers, ASAE.24 (1): $2-8$, ST. Joseph, MI, USA.

[22]Базаров Е.И. и др. Агрозооэнергетика (Agricultural and animal husbandry energetics), Moscow: Agropromizdat: Агропромиздат, 1987, 155 p. (in Russian)

[23]Ксеневич И.П., Гуськов В.В., Скойбеда А.Г., и др. Основы методики расчета параметров машинно-тракторного агрегата по критерию эффективности труда (Fundamentals of the methodology for calculating the parameters of a tractor-implement unit by the criterion of labor efficiency), Tractor and Implements: Тракторы и сельхозмашины, 1979, No.2, pp.15-18. (in Russian)

[24]Хафизов К.А. Пути снижения энергетических затрат на производственных процессах в сельском хозяйстве (Ways to reduce energy costs in production processes in agriculture). Kazan: Kazan State University Press, 2007. - 272 p. (in Russian)

[25] Хафизов К.А. Оптимизация параметров и режимов работы машинно-тракторных агрегатов на основе энергетического анализа (Optimization of parameters and operating modes of tractorimplement units based on energy analysis), Tractors and agricultural machinery: Тракторы и сельхозмашины, 2006, No.7, pp. 7-9. (in Russian)

[26] Новосельцев В.И. Теоретические основы системного анализа (Theoretical bases of the system analysis). Под ред. В.И. Новосельцева. - Moscow, Мajor: Майор, 2006, 592 p. (in Russian)

[27]Хафизов Р.Н., Хафизов К.А. Обоснование пределов изучаемой системы - машиннотракторный агрегат на посеве и выбор критерия оптимизации параметров тракторов (justification of limits of tractor-implement system under studied for seeding operation and choosing tractor optimization criteria), Conference materials: «Научное сопровождение агропромышленного комплекса: теория, практика, перспективы» Материалы международной научно-практической конференции, посвященной 65-летию образования 
Института механизации и технического сервиса, Kazan: Published by Kazan State Agrarian University, 2015, pp. 421 - 426. (in Russian)

[28] Хафизов К.А. Методика расчета МТА по критерию «Совокупные энергозатраты» (The methodology for calculating the TIU by the criterion "Aggregated energy costs".), Tractors and agricultural machinery: Тракторы и сельскохозяйственные машины, 2006, No.3., pp. 46 - 51. (in Russian).

[29] Хафизов К.А., Хафизов Р.Н. Результаты многофакторного эксперимента по определению зависимости максимального давления колес трактора на почву от параметров трактора и физико-механических свойств почвы. Статистический анализ (The results of a multifactorial experiment to determine the dependence of the maximum pressure of the tractor wheels on the soil on the parameters of the tractor and the physical and mechanical properties of the soil. Statistical analysis), Bulletin of Kazan State Agrarian University: Вестник Казанского государственного аграрного университета, 2016, № 4 (42), pp. 95-106. (in Russian)

[30] Хафизов К.А., Хафизов Р.Н. Результаты многофакторного эксперимента по определению зависимости максимального давления колес трактора на почву от параметров трактора и физико-механических свойств почвы. Анализ уравнений (The results of a multifactorial experiment to determine the dependence of the maximum pressure of the tractor wheels on the soil on the parameters of the tractor and the physical and mechanical properties of the soil. Analysis of equations) // Bulletin of Kazan State Agrarian University: Вестник Казанского государственного аграрного университета, 2016, No. 4 (42), pp. 107 - 116. (in Russian)

[31] Ходовые системы тракторов: (Устройство, эксплуатация, ремонт): Справочник (Chassis of tractors: (Design, operation, repair): Directory) / В. М. Забродский, А. М. Файнлейб, Л. Н. Кутин, О. Л. Уткин-Любовцов.- Moscow: Agropromizdat: Агропромиздат, 1986, 271 p. (in Russian)

[32] Захарченко А. Н., Лядин В. П., Джафари Наими К. Экспериментальные исследования воздействия колеса трактора на деформации почвы (Experimental studies of the effect of the tractor wheel on soil deformation), Доклады TCXA, Moscow, MSHA Press: Изд-во MCXA, 2007, Issue 279, pp 432-435. (in Russian) 